\title{
Fibronectin and Collagen IV Microcontact Printing Improves Insulin Secretion by INS1E Cells
}

Citation for published version (APA):

Hadavi, E., Leijten, J., Brinkmann, J., Jonkheijm, P., Karperien, M., \& van Apeldoorn, A. (2018).

Fibronectin and Collagen IV Microcontact Printing Improves Insulin Secretion by INS1E Cells. Tissue Engineering. Part C. Methods , 24(11), 628-636. https://doi.org/10.1089/ten.tec.2018.0151

Document status and date:

Published: 07/11/2018

DOI:

10.1089/ten.tec.2018.0151

Document Version:

Publisher's PDF, also known as Version of record

Document license:

Taverne

\section{Please check the document version of this publication:}

- A submitted manuscript is the version of the article upon submission and before peer-review. There can be important differences between the submitted version and the official published version of record.

People interested in the research are advised to contact the author for the final version of the publication, or visit the DOI to the publisher's website.

- The final author version and the galley proof are versions of the publication after peer review.

- The final published version features the final layout of the paper including the volume, issue and page numbers.

Link to publication

\footnotetext{
General rights rights.

- You may freely distribute the URL identifying the publication in the public portal. please follow below link for the End User Agreement:

www.umlib.nl/taverne-license

Take down policy

If you believe that this document breaches copyright please contact us at:

repository@maastrichtuniversity.nl

providing details and we will investigate your claim.
}

Copyright and moral rights for the publications made accessible in the public portal are retained by the authors and/or other copyright owners and it is a condition of accessing publications that users recognise and abide by the legal requirements associated with these

- Users may download and print one copy of any publication from the public portal for the purpose of private study or research.

- You may not further distribute the material or use it for any profit-making activity or commercial gain

If the publication is distributed under the terms of Article $25 \mathrm{fa}$ of the Dutch Copyright Act, indicated by the "Taverne" license above, 


\title{
Fibronectin and Collagen IV Microcontact Printing Improves Insulin Secretion by INS1E Cells
}

\author{
Elahe Hadavi, PhD, Jeroen Leijten, PhD, Jenny Brinkmann, $\mathrm{PhD},{ }^{2}$ Pascal Jonkheijm, $\mathrm{PhD}$, \\ Marcel Karperien, $\mathrm{PhD}$, and Aart van Apeldoorn, $\mathrm{PhD}^{1,3}$
}

\begin{abstract}
Extracellular matrix (ECM) molecules play significant roles in regulating $\beta$-cell function and viability within pancreatic islets by providing mechanical and biological support, stimulating cell survival, proliferation, and their endocrine function. During clinical islet transplantation, the $\beta$-cell's ECM environment is degraded by enzymatic digestion. Literature suggests that interactions between islet cells and ECM molecules, such as fibronectin (FN), collagen type IV (Col4), and laminin ( $\mathrm{LN})$, are essential for maintaining, or stimulation of islet function and survival, and can effect differentiation and proliferation of the endocrine cells. It is also thought that three-dimensional (3D) culture of $\beta$-cells can improve glucose responsiveness by providing a specific niche, in which cells can interact with each other in a more natural manner. Conventional suspension cultures with $\beta$-cells results generally in a heterogeneous population with small and large aggregates, in which cells experience different nutrient diffusion limitations, negatively affecting their physiology and function. In this study, we have explored the effect of FN, Col4, and LN111 on INS1E insulinoma cells by using microcontact printing $(\mu \mathrm{CP})$ to investigate whether a controlled environment and aggregate dimensions would improve their endocrine function. Using this method, we produced a pattern of well-defined circular spots of FN, Col4, and LN111 on polydimethylsiloxane with high spatial resolution. Cell seeding of the INS1E cells on these ECM protein spots resulted in the formation of 3D $\beta$-cell aggregates. We show that these INS1E aggregates have very reproducible dimensions, and that the cell culture method can be easily adjusted, leading to a highly accurate way of forming 3D $\beta$-cell aggregates on an ECM-functionalized substrate. In addition, we show that ECM molecules can act as anchoring points for $\beta$-cells on an otherwise non-cell-adherent material, and this can improve both the endocrine function and viability. We found a significant increase in the secretion of insulin by INS1E cells cultured on $\mu \mathrm{CP}$ FN and Col4 substrates, in comparison to cells that were growing in monolayers on substrates without ECM molecules. Moreover, INS1E cells growing on circular ECM spots in a 3D manner showed improved endocrine function in comparison to their two-dimensional counterparts.
\end{abstract}

Keywords: $\beta$-cells, type 1 diabetes, islet transplantation, $\beta$-cell replacement therapies, insulin secretion

\section{Impact Statement}

This research deals with finding a proper bioengineering strategy for the creation of improved $\beta$-cell replacement therapy in type 1 diabetes. It specifically deals with the microenvironment of $\beta$-cells and its relationship to their endocrine function.

\section{Introduction}

$\mathbf{C}$ LINICAL ISLET TRANSPLANTATION requires the isolation of islets from their pancreatic native environment. Isolation of islets is based on the enzymatic digestion of the pancreatic extracellular matrix (ECM), by using collagenase to separate the islets from the surrounding exocrine tissue, a process that also degrades the intraislet ECM. ${ }^{1,2} \mathrm{ECM}$ molecules are key microenvironmental factors that regulate numerous cellular processes in islets like, islet morphology, ${ }^{3}$ cell differentiation, ${ }^{4,5}$ intracellular signaling, ${ }^{6,7}$ gene expression, ${ }^{8,9}$ cell adhesion, ${ }^{10}$ cell migration, ${ }^{10,11}$ cell proliferation, ${ }^{12}$

\footnotetext{
${ }^{1}$ Department of Developmental BioEngineering, MIRA Institute for Biomedical Technology and Technical Medicine, Faculty of Science and Technology, University of Twente, Enschede, The Netherlands.

${ }^{2}$ MESA+ Institute for Nanotechnology, Molecular Nanofabrication Group, University of Twente, Enschede, The Netherlands.

${ }^{3}$ Complex Tissue Regeneration Department, MERLN Institute for Technology Inspired Regenerative Medicine, Maastricht University, Maastricht, The Netherlands.
} 
insulin secretion, ${ }^{10,13}$ and cell survival. ${ }^{12}$ It has been reported that enzymatic disruption of the $\beta$-cell-ECM interaction is partially responsible for the rapid loss of islets posttransplantation. ${ }^{1}$ In particular, fibronectin $(\mathrm{FN})$, collagen $(\mathrm{Col})$, and laminin (LN) are of high importance to $\beta$-cell function and survival. ${ }^{2,14-18}$

The enzymatic degradation of ECM molecules during islet isolation can lead to a loss of integrin binding, which can induce changes in phenotypic characteristics of $\beta$-cells. Consequently, this affects the endocrine cell function, morphology, and survival of pancreatic islet cells. ${ }^{19}$ The interaction of integrins, such as $\alpha_{3} \beta_{1}$ and $\alpha_{6} \beta_{1}$, with ECM was proven to affect insulin release; $\alpha_{\mathrm{v}} \beta_{3}$ and $\alpha_{\mathrm{v}} \beta_{5}$ integrins, for example, can regulate differentiation, adhesion, and migration of $\beta$-cells. ${ }^{20,21}$ In addition, $\beta$-cells express collagen type IV (Col4) binding $\alpha_{v} \beta_{1}$ integrin, which is associated with insulin release, cell motility, and cell adhesion. ${ }^{14,22}$ The pancreatic $\beta$-cells are also known to bind arginine-glycineaspartic acid (RGD) sequences on FN by integrins $\alpha_{3} \beta_{1}$, $\alpha_{5} \beta_{1}$, and $\alpha_{\mathrm{v}} \beta_{3}$, which promote cell survival. ${ }^{23,24}$ The density of these integrins decreases after enzymatic degradation of the islet basement membrane during isolation, which negatively affects the islet cell's endocrine function. ${ }^{19} \mathrm{Re}-$ introducing ECM molecules to $\beta$-cells has been reported to improve their survival and function. For example, culturing $\beta$-cells on ECM secreted by bovine corneal endothelial cells resulted in improved insulin release, ${ }^{25}$ islet survival, and proliferation. ${ }^{26}$ Furthermore, purified individual ECM molecules, such as collagen type I (Col1), Col4, LN, and FN, can increase the adhesion and insulin release of $\beta$-cells. ${ }^{14,22,27,28}$

Although previous studies have provided valuable insights, they were limited by conventional two-dimensional (2D) cultures of $\beta$-cells, which can negatively affect their metabolism and functionality. ${ }^{29,30}$ Microcontact printing $(\mu \mathrm{CP})$ can be used to create arrays of specific patterns of proteins on a non-cell-adherent material surface such as polydimethylsiloxane (PDMS), with high spatial resolution in a highly reproducible manner. ${ }^{31}$ By carefully designing a pattern consisting of one type of ECM molecule, or a mixture of different ECM molecules, one is able to create a welldefined cell culture substrate that allows one to study the influence of the $\beta$-cell microenvironment on their behavior and functionality.

In this study, we set out to optimize $\mu \mathrm{CP}$ to study the influence of a pattern of circular ECM spots on the function and behavior of $\beta$-cells. We hypothesize that INS1E $\beta$-cell function and viability can be improved by growing them on an ECM protein functionalized substrate, while growing $\beta$-cells into three-dimensional (3D) aggregates using the same ECM proteins guided by $\mu \mathrm{CP}$ could further help improve their endocrine function. To study the effect of biofunctionalized surfaces, we explored the effect of FN, Col4, and LN111 on the glucose responsiveness of rat INS1E insulinoma cells on uniformly coated tissue culture polystyrene in comparison to PDMS. We showed that uniform coatings of these ECM proteins on standard tissue culture plastic, and $\mu \mathrm{CP}$ spots of FN and Col4 on a soft PDMS substrate significantly increase the insulin secretion of INS1E cells compared to cells grown on noncoated tissue culture plastic controls. Interestingly, LN111 seems to adversely affect insulin secretion in comparison to cells grown on the noncoated surfaces. INS1E cells grown into 3D aggregates guided by the $\mu \mathrm{CP}$ ECM spots on
PDMS outperformed the same cells grown in a monolayer on uniformly coated tissue culture plastic in terms of relative insulin secretion per DNA. $\mu \mathrm{CP}$ revealed to be an effective manner to engineer uniform cell clusters by limiting cell adhesion to only the ECM-coated spots and guiding the formation of uniformly shaped and sized $\beta$-cell aggregates on and otherwise non-cell-adherent PDMS substrate. This study provides a method in which interactions of $\beta$-cells with ECM components can be studied in a very controlled manner. The $\mu \mathrm{CP}$ technique described in this report can be used to study the effect of ECM proteins on the endocrine function and behavior of $\beta$-cells, and guide the formation of equally sized and shaped 3D $\beta$-cell aggregates grown on demarcated functionalized micrometer-sized circular ECM spots.

\section{Materials and Methods}

\section{Fabrication of $\mu \mathrm{CP}$ substrates}

To fabricate $\mu \mathrm{CP}$ patterns of ECM molecules on a noncell adhesive PDMS substrate, we modified the method published by Mendelsohn et al. ${ }^{32}$ We used a silicon-based master wafer mold prepared by microphotolithography to create a pattern of ultra violet (UV) crosslinked SU8 to create PDMS-based stamps for printing. In brief, liquid SU8 is spin coated onto a silicon wafer, followed by selective UV polymerization using a photomask with a predefined pattern. The pattern design consists of 2500 circular spots $/ \mathrm{cm}^{2}$, each spot having a diameter of $100 \mu \mathrm{m}$. After photopolymerization, one is left with a negative replica of the intended pattern in SU8, which can be used as a mold for PDMS film casting. Subsequently, PDMS stamps with a thickness of 1$1.5 \mathrm{~mm}$ were prepared by negative replica molding using a 1:10 w/w mixture of Sylgard 184 elastomer (Dow Corning, USA). The stamps were treated by plasma oxidization (Plasma-Prep II plasma ether; SPI supplies, USA) at an oxygen pressure of $1.0 \mathrm{bar}$ and at $40 \mathrm{~mA}$ for $20 \mathrm{~s}$ to increase the hydrophilicity of PDMS, and to clean the surface from any remaining organic contaminants. Subsequently, the stamps were inked with $50 \mu \mathrm{L}$ of $100 \mu \mathrm{g} / \mathrm{mL}$ solubilized FN (rat derived), Col4 (human derived), or LN111 (mouse derived) (Merck-Millipore, The Netherlands; cat. no.: 341668, cat. no.: CC076, and cat. no.: CC095) in phosphate-buffered saline (PBS). We verified homogenous transfer of the proteins by labeling with the fluorophore DyLight 488 or 549 NHS Ester (Thermo Fisher Scientific) and fluorescence microscopy. Afterward, the excess inking solution of FN, Col4, or LN111 was removed from the stamp by washing with Milli-Q water and then dried under a stream of $\mathrm{N}_{2}$. PDMS cell culture substrates with a thickness of $3-5 \mathrm{~mm}$ were prepared by film casting on flat silicon wafers. The PDMS films were treated by plasma oxidization at an oxygen pressure of $1.0 \mathrm{bar}$ and at $40 \mathrm{~mA}$ for $90 \mathrm{~s}$. Subsequently, the micropatterned PDMS stamps were placed on the flat plasma-treated PDMS films for $20 \mathrm{~min}$. During transfer, a $25 \mathrm{~g} / \mathrm{cm}^{2}$ weight was placed on top of each stamp to ensure homogeneous transfer of the molecules on the underlying PDMS film, Successively, the nonprinted areas of the substrate were blocked by incubation of $10 \%$ w/v Pluronic F108 in PBS for $3 \mathrm{~h}$ at room temperature. After $\mu \mathrm{CP}$, the PDMS films were gently washed with PBS, disinfected with $70 \%$ ethanol for $2 \mathrm{~min}$ to ensure sterility, and washed with sterile PBS. Verification of homogenous and accurate printing was 
done by fluorescence microscopy. By using the abovementioned stamp configuration, we printed around 2420 spots per sample; $20 \%\left(\sim 1.9 \times 10^{7} \mu \mathrm{m}^{2}\right)$ of the total surface area of $1.5 \mathrm{~cm}$ diameter PDMS films is therefore covered with circular ECM protein containing spots. We compared the biofunctionalized ECM $\mu \mathrm{CP}$ PDMS samples with uniformly coated and noncoated tissue culture plastic (TCP) as controls.

\section{Cell culture}

INS1E rat insulinoma cells were cultured in RPMI 1640 medium with $2.05 \mathrm{mM}$ L-glutamine (Invitrogen, Carlsbad, CA) supplemented with $5 \%$ fetal bovine serum, $100 \mathrm{U} / \mathrm{mL}$ penicillin (GIBCO, Bleiswijk, The Netherlands), $100 \mathrm{U} / \mathrm{mL}$ streptomycin (Lonza, Verviers, Belgium), $10 \mathrm{mM}$ HEPES, $1 \mathrm{mM}$ sodium pyruvate, and $50 \mu \mathrm{M}$ freshly added $\beta$ mercaptoethanol. Cells were incubated in humidified air $\left(5 \% \mathrm{CO}_{2}\right)$ at $37^{\circ} \mathrm{C}$.

\section{Cell seeding density}

To have an equal cell density on the micropatterned substrates and tissue culture plastic samples, $4 \times 10^{5}$ INS1E cells $/ \mathrm{cm}^{2}$ were seeded on $\mu \mathrm{CP}$ FN-, Col4-, and LN111patterned PDMS, while $1 \times 10^{5} \mathrm{INS} 1 \mathrm{E}$ cells $/ \mathrm{cm}^{2}$ were seeded on uniformly coated and noncoated tissue culture plates (polystyrene). After $6 \mathrm{~h}$, the samples were supplemented with fresh medium. The cell seeding density was determined by quantifying the DNA content per sample in triplicate using a Quant-iT Pico-Green dsDNA assay kit (Invitrogen) according to the manufacturer's protocol.

\section{Cell morphology}

To study the effect of the $\mu \mathrm{CP}$ ECM proteins on INS1E cell morphology, samples were fixed in $4 \%(\mathrm{w} / \mathrm{v})$ paraformaldehyde in PBS for $1 \mathrm{~h}$ at room temperature after 1, 3, and 7 days of culture. Subsequently, samples were dehydrated using an increasing concentration series of ethanol from $70 \%$ to $100 \%$ for $30 \mathrm{~min}$ in each step. Afterwards, samples were prepared for scanning electron microscopy using a Balzer's CPD 030 and BAL-TEC critical point dryer, and gold coated by a sputter coater (Cressington, UK). Electron micrographs were made using an XL30 ESEM-FEG environmental scanning electron microscope (Philips/FEI, The Netherlands). Furthermore, to verify cell growth, samples from each experimental condition were fixed in $4 \%(\mathrm{w} / \mathrm{v})$ paraformaldehyde in PBS for $1 \mathrm{~h}$ at room temperature during cell culture at 3 and 7 days and imaged using standard bright-field phase contrast microscopy (Nikon TE300, Japan).

\section{Cell viability}

A two-color fluorescent LIVE/DEAD viability/cytotoxicity Kit (Invitrogen) was used to evaluate the viability of INS1E cells at each time point. The assay was performed on cells cultured on noncoated and uniformly coated tissue culture plastic plates, and $\mu \mathrm{CP}$ PDMS films functionalized with ECM proteins after 3 and 7 days. Green fluorescent Calcein AM indicates live cells by labeling intracellular esterase, and red fluorescent Ethidium homodimer-1 indicates dead cells by complexation to DNA, which can only occur when plasma membranes are damaged. Samples $(n=3)$ were imaged using confocal fluorescence microscopy (Olympus $1 \times 71$, Japan). Cell viability was determined by fluorescence as the percentage of Calcein AM-positive cells versus Ethidium homodimer-1-positive cells of the total amount of cells observed (Fig. 2).

\section{Glucose-stimulated insulin secretion test}

Glucose-stimulated insulin secretion tests were performed on INS1E cells after 3 and 7 days of culture ( $n=3 /$ condition). Each sample was preincubated for $1 \mathrm{~h}$ in a glucosefree incubation buffer consisting of a modified Krebs-Ringer bicarbonate buffer with HEPES and $10 \mathrm{mM}$ theophylline (KRBH) containing $115 \mathrm{mmol} / \mathrm{L} \mathrm{NaCl}, 5 \mathrm{mmol} / \mathrm{L} \mathrm{KCL}$, $24 \mathrm{mmol} / \mathrm{L} \mathrm{NaHCO} 3,2.2 \mathrm{mmol} / \mathrm{L} \mathrm{CaCl}_{2}, 1 \mathrm{mmol} / \mathrm{L} \mathrm{MgCl}_{2}$, $20 \mathrm{mmol} / \mathrm{L} \mathrm{HEPES}$, and $2 \mathrm{~g} / \mathrm{L}$ human serum albumin at $\mathrm{pH}$ 7.4. Subsequently, samples were incubated during three consecutive steps, exposing them to low glucose $(1.6 \mathrm{mmol} /$ $\mathrm{L})$, high glucose $(16.7 \mathrm{mmol} / \mathrm{L})$, and another low glucose ( $1.6 \mathrm{mmol} / \mathrm{L}$ ) containing $\mathrm{KRBH}$ buffer for $90 \mathrm{~min}$ at $37^{\circ} \mathrm{C}$ each time. Tissue culture media samples were collected after each incubation step and analyzed for insulin content using an ELISA assay (Mercodia, Uppsala, Sweden) according to the manufacturer's protocol. Finally, the total amount of cells was determined by DNA quantification as described above. Subsequently, the DNA measurements were used to compare the relative insulin secretion in each experimental condition to each other by normalizing the insulin secretion to DNA, allowing one to determine the glucose responsiveness of $\beta$-cells between the different samples irrespective of total cell number/condition.

\section{Statistical analysis}

We presented glucose responsiveness of INS1E cells as mean insulin secretion $(\mathrm{pMol} / \mu \mathrm{g}$ DNA) \pm standard deviation. Statistical analysis was performed using a Student's $t$ test, one-way analysis of variance, and a least-significant difference multiple comparison test by application of SPSS statistic software (Chicago, IL). Statistical significance was considered at $p<0.05$.

\section{Results \\ $\mu C P$ of ECM molecules}

To evaluate the effect of ECM molecules on function, viability, and morphology of the INS1E cells, three different ECM molecules were applied as a uniform coating or $\mu \mathrm{CP}$ pattern (Fig. 1A). FN, Col4, and LN111 were selected due to their abundance in islets and their previously reported roles on $\beta$-cell behavior. Cell cultures on noncoated tissue culture plastic plates served as negative controls. Fluorescence microscopy indicated that homogenous $100 \mu \mathrm{m}$ diameter circular spots were $\mu \mathrm{CP}$ with FN, Col4, or LN111 (Fig. 1B, C). Evaluation of the fluorescent intensity indicated that the covalently immobilized FN, Col4, and LN111 remained stable for at least 7 days after $\mu \mathrm{CP}$ (Fig. 1D). After seeding INS1E cells on $\mu \mathrm{CP}$ substrates, the cells only adhered to the ECM containing spots and after proliferation formed equally shaped and sized rounded aggregates (Fig. 1E). Since cellcell interactions can play an important role in $\beta$-cell function, we ensured that identical cell amounts in each condition were used at the start of each culture. The initial cell seeding 


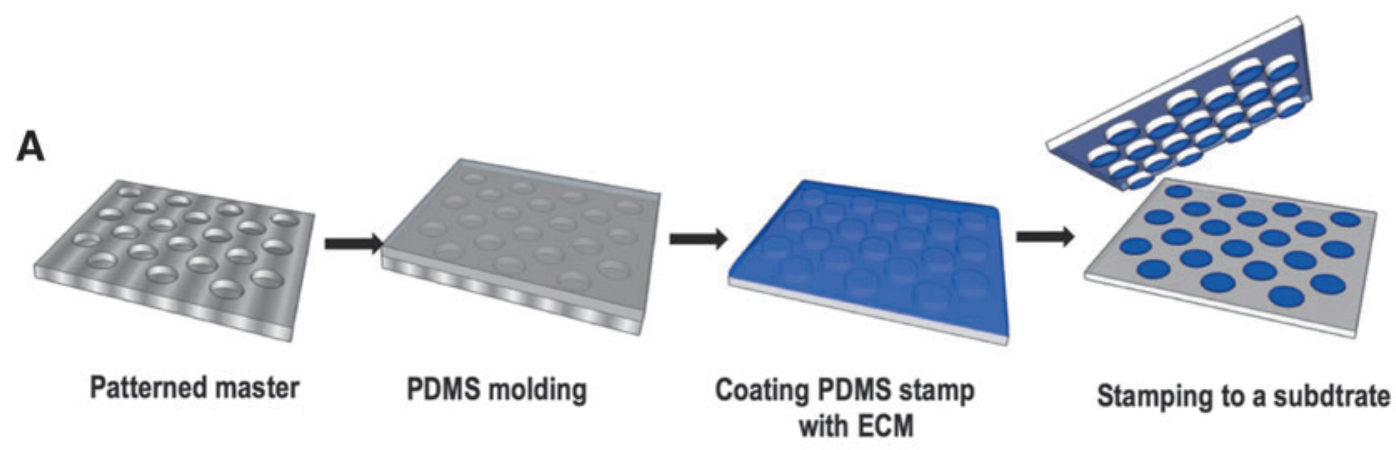

B

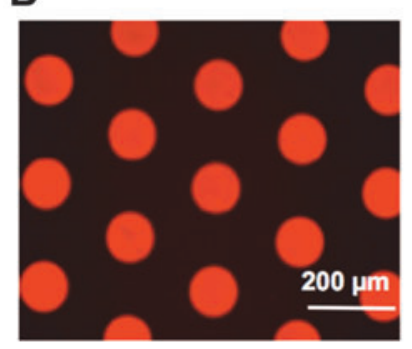

C

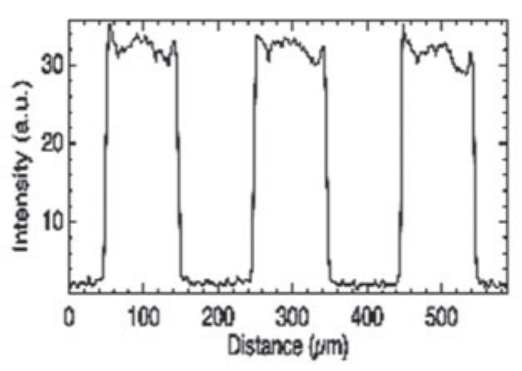

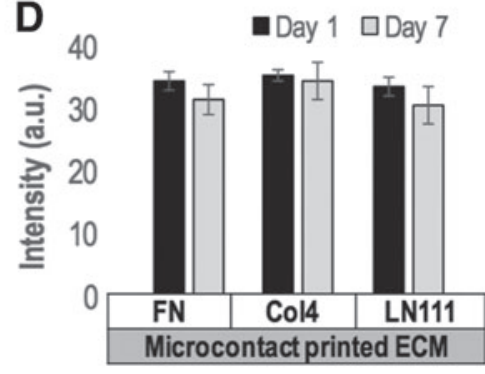

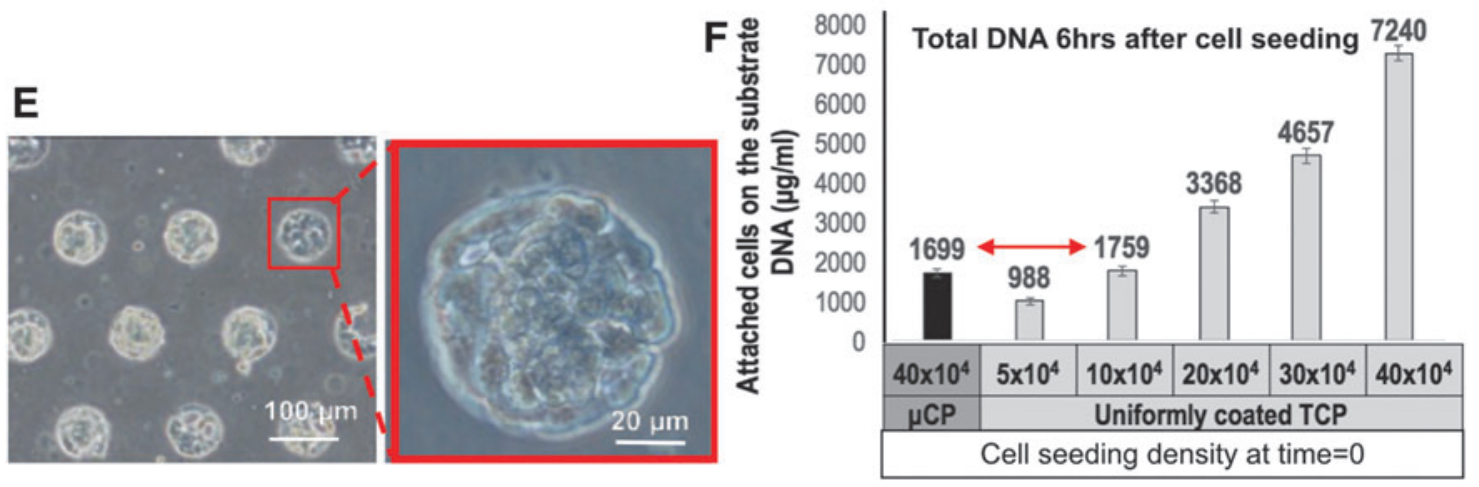

FIG. 1. Fabrication of cell-seeded ECM $\mu$ CP substrates. (A) Schematic outline of the creation of the $\mu C P$ ECM arrays. (B) Homogenous distribution of fluorescently labeled FN validated proper homogenous transfer of ECM proteins. (C) Homogeneity of the $\mu \mathrm{CP}$ spots was confirmed using fluorescence intensity distribution quantification. (D) Consecutive fluorescent intensity measurements of $\mu \mathrm{CP} \mathrm{FN}, \mathrm{Col} 4$, and LN111 demonstrated that the patterns were stable in cell culture medium at $37^{\circ} \mathrm{C}$ for at least 7 days. (E) INS1E cells were able to grow on $\mu \mathrm{CP}$ spots, but not on nonprinted areas. (F) An equal cell density between patterned and nonpatterned, or uniformly coated substrates was determined using DNA quantification. $\mu \mathrm{CP}$, microcontact printing; Col4, collagen type IV; ECM, extracellular matrix; FN, fibronectin; LN, laminin; PDMS, polydimethylsiloxane; TCP, tissue culture plastic. Color images available online at www.liebertpub.com/tec

amount in each condition was verified by a series of cell seeding optimization steps, after which the total amount of DNA present after cell had adhered was determined. On $\mu C P$ PDMS samples we printed, the entire surface $\left(1.9 \times 10^{7}\right.$ $\mu \mathrm{m}^{2}$ of $1 \mathrm{~cm}^{2}$ ) is covered with circular cell-adherent ECM spots, while in control samples, cells can adhere to the entire surface. Cells unable to adhere were removed $6 \mathrm{~h}$ after seeding when the medium was refreshed before DNA analysis. Based on these outcomes, $4 \times 10^{5} \mathrm{INS} 1 \mathrm{E}$ cells $/ \mathrm{cm}^{2}$ on $\mu$ CP FN, Col4, and LN111 substrates, and $1 \times 10^{5}$ INS1E cells $/ \mathrm{cm}^{2}$ on noncoated and uniformly coated samples were used for cell seeding in the follow-up experiments (Fig. 1F).

\section{Viability of INS1E cells on micropatterns of ECM}

To validate the cytocompatibility of INS1E cells on ECM micropatterned substrates, the viability of INS1E cells cul- tured on conventional ECM coatings and $\mu \mathrm{CP}$ ECM spots was investigated after 1 and 7 days (Fig. 2A). Uncoated tissue culture plastic was used as a control. Live/dead staining revealed cell viability of around $90 \%$ for all $\mu \mathrm{CP}$ samples after 1 and 7 days of culture. The relative percentage of viable cells on $\mu \mathrm{CP}$ ECM spots was somewhat higher than those of INS1E cells cultured on either uniformly coated, or noncoated tissue culture plastic samples after 7 days. No major differences between all groups were observed as can be seen in the comparative histology (Fig. 2B).

\section{$\mu C P$ ECM spots induce INS1E cells to form 3D aggregates}

We assessed the effect of $\mu \mathrm{CP}$ FN, Col4, and LN111 on INS1E cell morphology using SEM after 1, 3, and 7 days of culture. The results indicated that INS1E cells initially 
FIG. 2. Evaluation of the cell viability in the presence of FN, Col4, and laminin 111 on a nonpatterned (uniformly coated) TCP plate and $\mu \mathrm{CP}$ PDMS. (A) Live/dead staining of INS1E cells on days 1 and 7. (B) Image-based semiquantification of the amount of live and dead cells after 7 days. Color images available online at www .liebertpub.com/tec

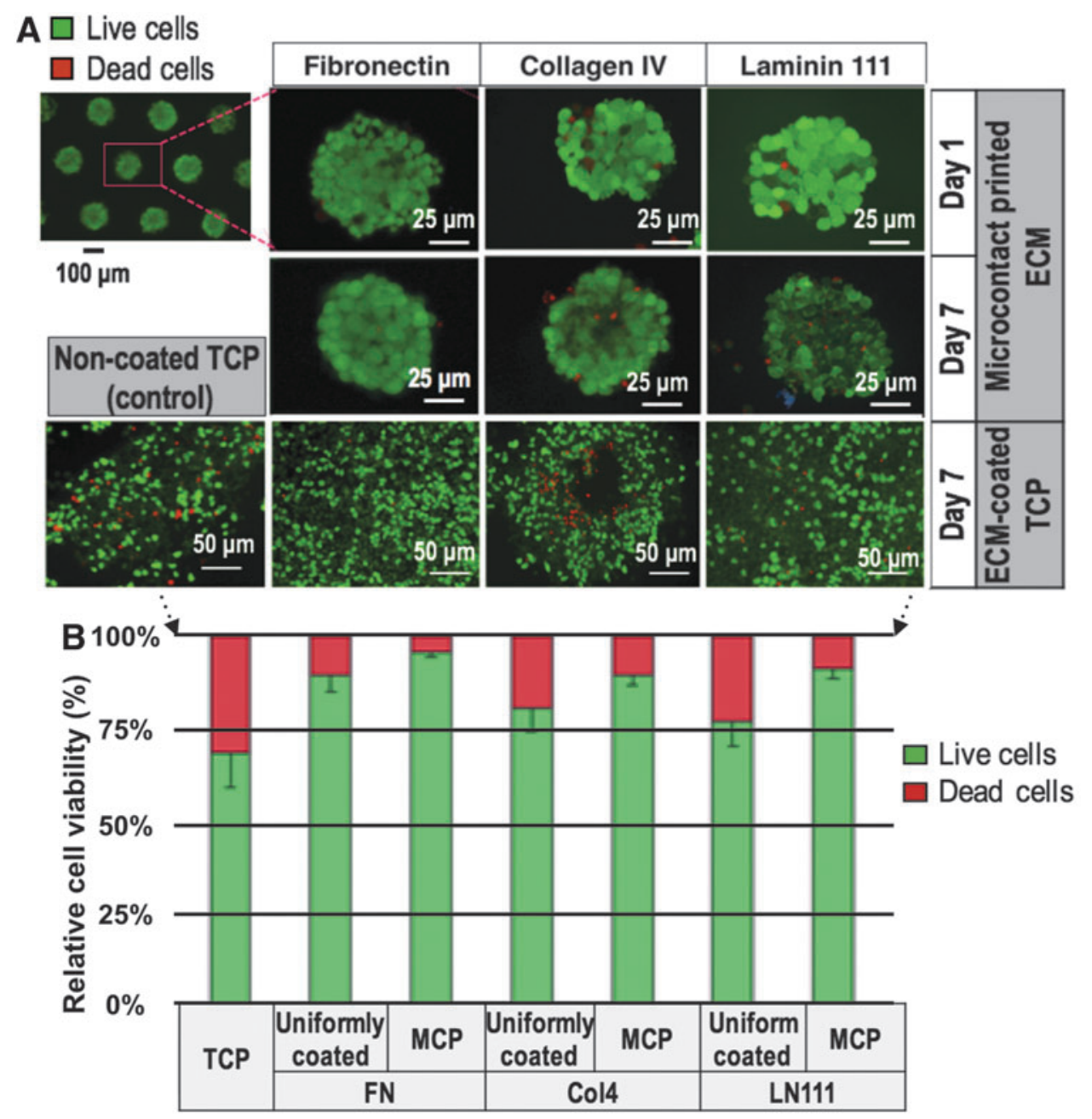

attach in a homogeneous manner to the $\mu \mathrm{CP}$ ECM spots. Subsequently, the cells grow into a monolayer on day 1, then form a multilayer on day 3 , and ultimately form $3 \mathrm{D}$ rounded $\beta$-cell aggregates on day 7 (Fig. 3A). On day 7 , the aggregate dimensions were as follows: width $72 \pm 10,76 \pm 9$, and $75 \pm 12 \mu \mathrm{m}$, height of $23.3 \pm 3.6,38.7 \pm 4.8$, and $41.5 \pm$ $4.2 \mu \mathrm{m}$ for FN, Col4, and LN111 $\mu \mathrm{CP}$ spots (Fig. 3B, C). To determine the number of INS1E cells, which had adhered to the nonprinted and $\mu \mathrm{CP}$ samples after 3 and 7 days, we determined the total amount of DNA after each time point. Although all samples had initially been seeded with the same number of cells at the start of the experiment, we found that the DNA content on the $\mathrm{LN} 111 \mu \mathrm{CP}$ samples was higher than those of the Col4- and FN-printed samples (Fig. 3D). In detail, the DNA content for control samples as well as homogenously coated samples with FN, Col4, and LN was 5,400 $\pm 3000,25,100 \pm 4500,35,300 \pm 7000$, and $43,400 \pm 9000 \mu \mathrm{g} / \mathrm{mL}$ on day 7 . Moreover, the DNA content on day 7 for $\mu \mathrm{CP}$ FN, Col4, and LN samples was 20,600 \pm $3000,28,200 \pm 5000$, and 38,200 $\pm 5700 \mu \mathrm{g} / \mathrm{mL}$ (Fig. 3D).

\section{Glucose responsiveness of INS1E cell clusters}

Glucose-stimulated insulin secretion of INS1E cells was assessed in INS1E cells cultured on $\mu$ CP PDMS substrates, nonpatterned TCP plates, and noncoated TCP plates after
7 days. Insulin secretion was significantly higher in cells

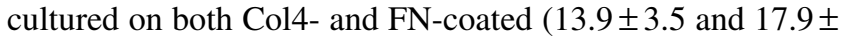
$4.8 \mathrm{picomol} / \mu \mathrm{g}$ DNA) and $\mu \mathrm{CP}(11.6 \pm 1.5$ and $15.5 \pm 2 \mathrm{pi}-$ comol/ $\mu$ g DNA) samples compared to tissue culture plastic control samples $(6.2 \pm 1.0 \mathrm{picomol} / \mu \mathrm{g}$ DNA). In contrast, cells cultured on both coated and $\mu \mathrm{CP}$ LN111 samples showed reduced insulin secretion $(1.2 \pm 0.1$ and $3.8 \pm 0.9$ picomol/ $\mu$ g DNA) compared to the control group. Regardless of which ECM protein was used, the insulin secretion was significantly higher when cells were grown on $\mu \mathrm{CP}$ PMDS surfaces compared to uniformly coated tissue culture plastic surfaces.

\section{Discussion}

ECM molecules play a prominent role in the cellular microenvironment where they can influence function, survival, morphology, proliferation, and differentiation of cells. Isolation of islets from their native microenvironment using enzymatic digestion disrupts the interaction between the islet cells and important ECM molecules such as FN, Col4, and $\mathrm{Lm}^{1,2}$ Improving the interaction of insulin-producing $\beta$ cells with inert biomaterial surfaces by ECM proteins can be an interesting strategy to help restore the lost ECM and mimic the pancreatic islet microenvironment. 

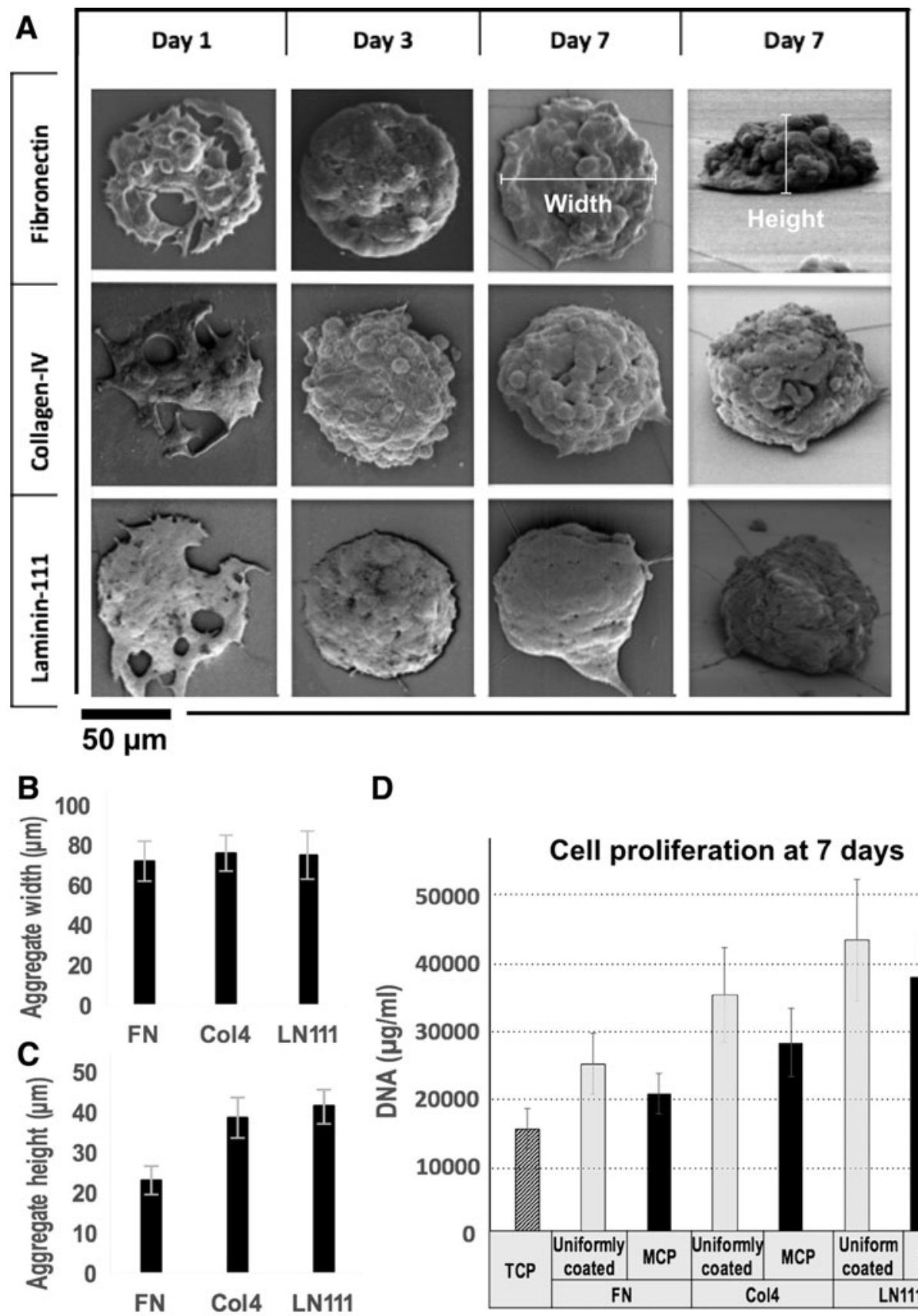

D

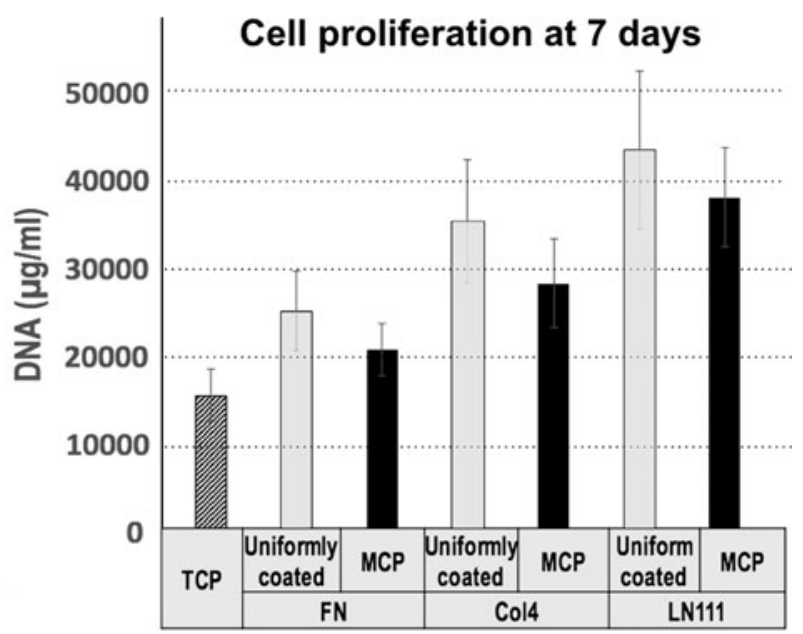

FIG. 3. (A) Electron micrographs of INS1E cells cultured on $\mu \mathrm{CP}$ FN, Col4, and LN111 substrates after 1 , 3 , and 7 days of culture. (B) Height of aggregates on FN, Col4, and LN111 $\mu \mathrm{CP}$ substrates after 7 days. (C) Width of the aggregates on $\mathrm{FN}, \mathrm{Col} 4$, and $\mathrm{LN} 111 \mu \mathrm{CP}$ substrates. (D) The total cell number of INS1E cells on $\mu \mathrm{CP}$ and coated $\mathrm{FN}, \mathrm{Col} 4$, and LN111 after 7 days of culture.
In this study, we report on the effect of $\mu \mathrm{CP} \mathrm{FN}, \mathrm{Col} 4$, and LN111 on INS1E cells cultured on PDMS and tissue culture polystyrene. $\mu \mathrm{CP}$ provides an easy method to study the interaction between cells and ECM proteins on a micropatterned functionalized PDMS substrate to which cells normally do not adhere due to its hydrophobic properties. Recently, many studies have focused on minimizing the drawbacks of $\mu \mathrm{CP}$ on soft pliable surfaces, such as inktransfer issues and stamp deformation. We compared $\beta$-cell behavior on uniformly coated and $\mu \mathrm{CP}$ surfaces comprising either a uniform coating of FN, Col4, or LN111 or circular printed spots with a diameter of $100 \mu \mathrm{m}$ of the same ECM molecules on PDMS. Consecutive fluorescent intensity measurements of $\mu \mathrm{CP} \mathrm{FN,} \mathrm{Col4,} \mathrm{and} \mathrm{Lm} \mathrm{patterns} \mathrm{demon-}$ strated that the ECM proteins were homogeneously transferred and remained stable in medium at $37^{\circ} \mathrm{C}$ for at least 7 days. After cell seeding and prolonged culture, the micropatterned ECM spots enabled aggregation of INS1E cells into similarly shaped rounded aggregates with an average size of around $75 \mu \mathrm{m}$ (diameter) $\times 35 \mu \mathrm{m}$ (height). We observed that in these multilayered cell aggregates, only the cells on the bottom were in direct contact with the underlying $\mu \mathrm{CP}$ biofunctionalized substrate. Previous studies indicated that cell-cell contact and islet size are important factors influencing the function and survival of $\beta$-cells. Some studies indicate that relatively large aggregates $(>150 \mu \mathrm{m})$ quickly lead to apoptosis of $\beta$-cells, ultimately resulting in loss of endocrine function. ${ }^{33,34}$ Moreover, while 
$\beta$-cell clusters of $\sim 100 \mu \mathrm{m}$ diameter do not demonstrate a significant amount of cell loss by apoptosis, they were reported to secrete less insulin compared to smaller $(<100 \mu \mathrm{m})$ $\beta$-cell clusters, suggesting that diffusion limitation might not be the cause, but cell-cell interactions. ${ }^{35}$

Our results revealed that the FN- and Col4-coated spots prepared by $\mu \mathrm{CP}$ on PDMS can improve the function of INS1E cells compared to cells grown on noncoated tissue culture plastic surfaces. We observed that the amount of DNA isolated from INS1E cell cultures on Col4 and LN111 uniformly coated tissue culture plastic or $\mu \mathrm{CP}$ PDMS samples was considerably higher after 7 days then on noncoated tissue culture plastic control samples, while in all conditions, an equal amount of cells was seeded, suggesting a lower proliferation rate in the latter conditions. These observations suggest a positive effect on INS1E proliferation when they are in contact with Col4 or LN111. In contrast, the glucose responsiveness of INS1E cells in the presence of LN111 was significantly less than when in contact with FN and Col4, as can be seen in Figure 4. This suggests that LN111 plays an important role in cell proliferation rather than enhancing the glucose responsiveness of INS1E cells. In all conditions where biofunctionalized ECM surfaces were used as a cell culture substrate, the insulin secretion was significantly higher in cells cultured on $\mu \mathrm{CP}$ PDMS surfaces compared to uniformly coated tissue culture plastic controls. Although there is an obvious difference in mechanical properties between PDMS and tissue culture plastic (polysterene), which might influence cell behavior, most cells in 3D aggregates are not directly exposed to the underlying substrate. The intensified cell-cell contacts due to the formation of 3D aggregates by INS1E cells guided by the ECM $\mu \mathrm{CP}$ spots could possibly explain the improved insulin secretion, since cells grown into 2D monolayers have less 3D cell-cell interactions. Our findings regarding aggregate formation are in line with a study performed by Mendelsohn et al., ${ }^{32}$ who showed that with the same cell- type aggregate formation occurs on $\mu \mathrm{CP}$ surfaces with square spots. Although they only performed a 24-h cell culture with varying spot dimensions, they observed the formation of multilayered aggregates on $60 \times 60 \mu \mathrm{m}$ square spots and suggested that with sufficient cell seeding numbers, a multilayered aggregate can be formed on larger square-shaped spots of LN in $24 \mathrm{~h}^{32}$ A possible reason for the enhanced insulin secretion could be that cells directly in contact with the underlying ECM proteins are performing better due to this interaction, while the cells above perform better due to more intense cellular interactions. There are a number of studies that support our observations that $\mathrm{FN}$ and Col4 can improve the glucose responsiveness of $\beta$-cells. ${ }^{36,37}$ It has been reported that $\mathrm{FN}$ increases insulin secretion at a similar level as RGD-functionalized substrates, ${ }^{38}$ which suggests the importance of the RGD-integrin binding. Some studies have shown a positive role of LN111 on survival, differentiation, and insulin gene expression of islets. ${ }^{39,40}$ However, information on the effect of different laminins remains scarce and underlying mechanism of the effect of LN111 on insulin release has not been unraveled yet, and warrants a more elaborate study in the future. A more dedicated study using biofunctionalized surfaces, using various combinations of ECM molecules on primary islet cells could elucidate which integrins and signal transduction pathways are involved to stimulate their endocrine function and what exact role-specific combinations of ECM proteins play in the $\beta$-cell niche. In this study, we observed a positive effect of Col4 and LN111 on cell proliferation, an outcome which is in line with observation done by Weber et al., ${ }^{13}$ who showed a positive effect on the survival rate of $\beta$-cells when ECM molecules were used in 3D cultures. These observations seem to be dependent on different culture systems with inherent higher cell survival rates. For example, encapsulation of the MIN6-B1 cells in hydrogels without ECM molecules has resulted in high survival rates, suggesting that an entirely $3 \mathrm{D}$ culture perhaps better mimics
FIG. 4. Glucose-stimulated insulin secretion test of INS1E cells on nonpatterned (uniformly coated), and $\mu \mathrm{CP} \mathrm{FN}, \mathrm{Col} 4$, and LN111 after 7 -day cell culture. *Indicates significant differences between groups $(p<0.05)$.

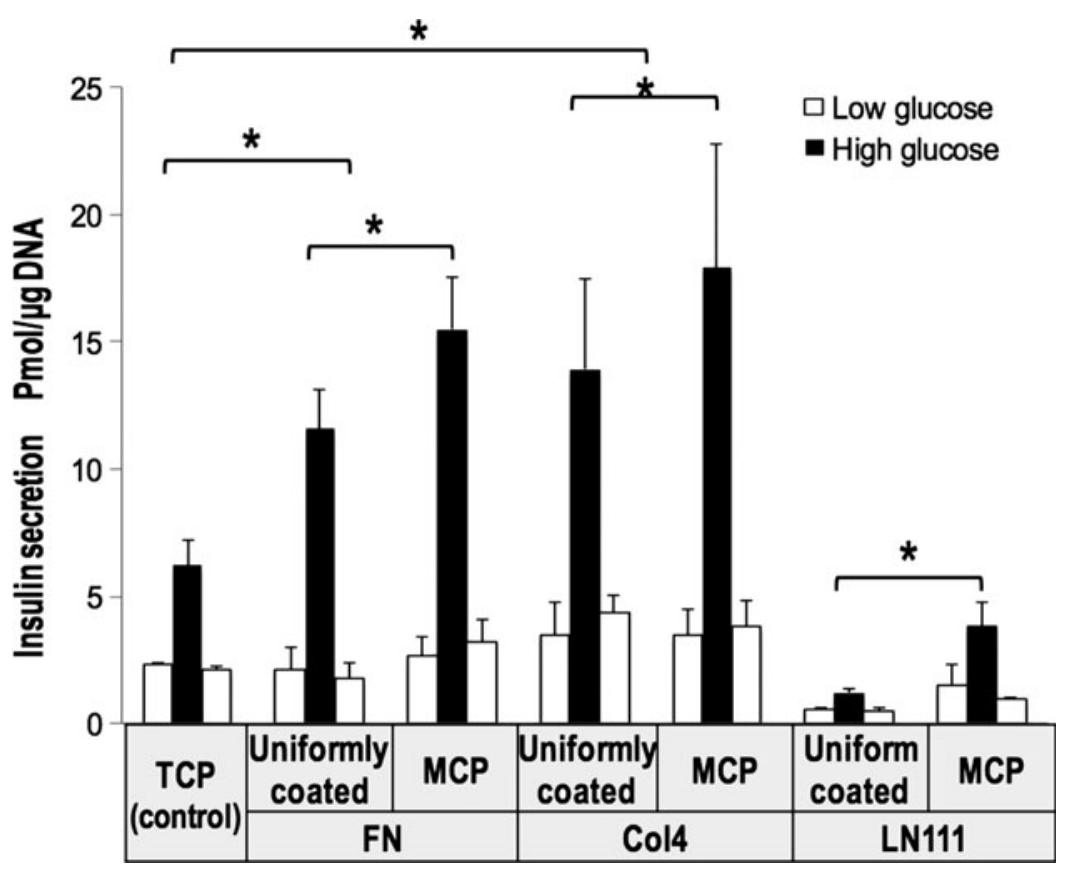


the native rounded islet morphology leading to improved cell behavior. $^{13,41}$

Comparative morphology of the different aggregates cultured on the different ECM molecules showed that cells cultured on $\mu \mathrm{CP}$ spots of LN111 assemble into more compact aggregates than cells cultured on FN and Col4, a behavior that could potentially negatively affect their endocrine function. There is currently no study available regarding the effect of laminins on compaction of $\beta$-cells in literature. However, some studies suggest that extracellular stimuli, as well as cell-cell adhesion molecules, can regulate specific cell signaling involved in morphological changes of epithelial cells. ${ }^{42}$

\section{Conclusions}

We demonstrated that FN, Col4, and LN111 are homogenously printable by $\mu \mathrm{CP}$ on a flat PDMS surface. Our results indicated that $\mu \mathrm{CP}$ provides an effective method to reproducibly enable the formation of well-defined $\beta$-cell aggregates. Moreover, we revealed that $\mu \mathrm{CP}$-guided $3 \mathrm{D}$ cell aggregate formation can improve the function of INS1E cells compared to conventional $2 \mathrm{D}$ monolayer cultures. $\beta$ Cells cultured on conventionally ECM-coated surfaces do not present a natural 3D rounded morphology, and display lesser endocrine function, compared to cells cultured in 3D aggregates on ECM $\mu \mathrm{CP}$ surfaces. In this study, we reported that $\mu \mathrm{CP}$ can be used to enable formation of $\beta$-cells into 3D aggregates to study the effect of cell-cell and ECM-cell interactions and their endocrine function. This approach holds great potential for applications in tissue regeneration and drug discovery, stem cell research, and many other cellbased analyses and devices. We showed that $\mu \mathrm{CP}$ can provide an interesting technology platform to study the effect of ECM molecules on $\beta$-cells for the development of improved functionalized biomaterials and scaffolds for treatment of type 1 diabetes.

In this study, we reported on a method to generate welldefined $\beta$-cell aggregates of $\sim 75 \mu \mathrm{m}$ diameter in a highly reproducible and controlled manner using $\mu \mathrm{CP}$ circular ECM spots on non-cell-adherent PDMS. We showed that FN and Col4 can have a positive effect on glucose responsiveness of INS1E cells, but that LN111 does not. Col4 and LN111 seem to positively affect the proliferation of INS1E cells, while the formation of $3 \mathrm{D}$ aggregates guided by $\mu \mathrm{CP}$ ECM on PDMS significantly improves insulin secretion in comparison to $2 \mathrm{D}$ cell cultures on tissue culture plastic surfaces. One has to keep in mind that ECM molecules in tissues form an intricate network and different molecules can act simultaneously on cells residing in this matrix. In vitro systems cannot entirely mimic this complex microenvironment, and this and other studies are limited by the source of ECM proteins used and their availability. Based on the outcomes of this study, we think that further studies on the effect of different combinations of ECM proteins on primary islet cells could lead to more insight in how the pancreatic islet niche can affect $\beta$-cell behavior.

\section{Acknowledgments}

This research was financially supported by the Diabetes Cell Therapy Initiative (DCTI) FES 2009 program LSHDCTI, including the Dutch Diabetes Research Foundation
(DF). Dr. Leijten acknowledges personal financial support from the Dutch NWO innovative research incentives scheme Veni award (No. 14328) and the European Research Council (ERC, Starting Grant, No. 759425).

\section{Disclosure Statement}

No competing financial interests exist.

\section{References}

1. Cross, S.E., Hughes, S.J., Partridge, C.J., Clark, A., Gray, D.W., and Johnson, P.R. Collagenase penetrates human pancreatic islets following standard intraductal administration. Transplantation 86, 907, 2008.

2. Rosenberg, L., Wang, R., Paraskevas, S., and Maysinger, D. Structural and functional changes resulting from islet isolation lead to islet cell death. Surgery 126, 393, 1999.

3. Thivolet, C.H., Chatelain, P., Nicoloso, H., Durand, A., and Bertrand, J. Morphological and functional effects of extracellular matrix on pancreatic islet cell cultures. Exp Cell Res 159, 313, 1985.

4. Montesano, R., Mouron, P., Amherdt, M., and Orci, L. Collagen matrix promotes pancreatic endocrine cell. J Cell Biol 97, 935, 1983.

5. Jiang, F.X., Cram, D.S., DeAizpurua, H.J., and Harrison, L.C. Laminin-1 promotes differentiation of fetal mouse pancreatic beta-cells. Diabetes 48, 722, 1999.

6. Peiris, H., Bonder, C.S., Coates, P.T.H., Keating, D.J., and Jessup, C.F. The $\beta$-cell/EC axis: how do islet cells talk to each other? Diabetes 63, 3, 2014.

7. Rondas, D., Tomas, A., Soto-Ribeiro, M., Wehrle-Haller, B., and Halban, P.A. Novel mechanistic link between focal adhesion remodeling and glucose-stimulated insulin secretion. J Biol Chem 287, 2423, 2012.

8. Daoud, J., Petropavlovskaia, M., Rosenberg, L., and Tabrizian, $M$. The effect of extracellular matrix components on the preservation of human islet function in vitro. Biomaterials 31, 1676, 2010.

9. Boretti, M.I., and Gooch, K.J. Effect of extracellular matrix and $3 \mathrm{D}$ morphogenesis on islet hormone gene expression by Ngn3-infected mouse pancreatic ductal epithelial cells. Tissue Eng Part A 14, 1927, 2008.

10. Edamura, K., Nasu, K., Iwami, Y., Ogawa, H., Sasaki, N., and Ohgawara, H. Effect of adhesion or collagen molecules on cell attachment, insulin secretion, and glucose responsiveness in the cultured adult porcine endocrine pancreas: a preliminary study. Cell Transplant 12, 439, 2003.

11. Ryschich, E., Khamidjanov, A., Kerkadze, V., Büchler, M.W., Zöller, M., and Schmidt, J. Promotion of tumor cell migration by extracellular matrix proteins in human pancreatic cancer. Pancreas 38, 804, 2009.

12. Beattie, G.M., Rubin, J.S., Mally, M.I., Otonkoski, T., and Hayek, A. Regulation of proliferation and differentiation of human fetal pancreatic islet cells by extracellular matrix, hepatocyte growth factor, and cell-cell contact. Diabetes 45, 1223, 1996.

13. Weber, L.M., Hayda, K.N., and Anseth, K.S. Cell-matrix interactions improve $\beta$-cell survival and insulin secretion in three-dimensional culture. Tissue Eng Part A 14, 1959, 2008.

14. Kaido, T., Yebra, M., Cirulli, V., and Montgomery, A.M. Regulation of human $\beta$-cell adhesion, motility, and insulin secretion by collagen IV and its receptor $\alpha 1 \beta 1$. J Biol Chem 279, 53762, 2004. 
15. Hamamoto, Y., Fujimoto, S., Inada, A., et al. Beneficial effect of pretreatment of islets with fibronectin on glucose tolerance after islet transplantation. Horm Metab Res 35, 460, 2003.

16. Jiang, F.X., Naselli, G., and Harrison, L.C. Distinct distribution of laminin and its integrin receptors in the pancreas. J Histochem Cytochem 50, 1625, 2002.

17. Mandrup-Poulsen, T. beta-cell apoptosis: stimuli and signaling. Diabetes 50, S58, 2001.

18. Lucas-Clerc, C., Massart, C., Campion, J.P., Launois, B., and Nicol, M. Long-term culture of human pancreatic islets in an extracellular matrix: morphological and metabolic effects. Mol Cell Endocrinol 94, 9, 1993.

19. Wang, R.N., Paraskevas, S., and Rosenberg, L. Characterization of integrin expression in islets isolated from hamster, canine, porcine, and human pancreas. J Histochem Cytochem 47, 499, 1999.

20. Cirulli, V., Beattie, G.M., Klier, G., et al. Expression and function of $\alpha v \beta 3$ and $\alpha v \beta 5$ integrins in the developing pancreas. J Cell Biol 150, 1445, 2000.

21. Kantengwa, S., Baetens, D., Sadoul, K., Buck, C.A., Halban, P.A., and Rouiller, D.G. Identification and characterization of $\alpha 3 \beta 1$ integrin on primary and transformed rat islet cells. Exp Cell Res 237, 394, 1997.

22. Kaido, T., Perez, B., Yebra, M., et al. av-Integrin utilization in human $\beta$-cell adhesion, spreading, and motility. $\mathrm{J}$ Biol Chem 279, 17731, 2004.

23. Stendahl, J.C., Kaufman, D.B., and Stupp, S.I. Extracellular matrix in pancreatic islets: relevance to scaffold design and transplantation. Cell Transplant 18, 1, 2009.

24. Pinkse, G.G., Bouwman, W.P., Jiawan-Lalai, R., Terpstra, O.T., Bruijn, J.A., and de Heer, E. Integrin signaling via RGD peptides and anti- $\beta 1$ antibodies confers resistance to apoptosis in islets of Langerhans. Diabetes 55, 312, 2006.

25. Beattie, G.M., Lappi, D.A., Baird, A., and Hayek, A. Functional impact of attachment and purification in the short term culture of human pancreatic islets. J Clin Endocrinol Metab 73, 93, 1991.

26. Schuppin, G.T., Bonner-Weir, S., Montana, E., Kaiser, N., and Weir, G.C. Replication of adult pancreatic-beta cells cultured on bovine corneal endothelial cell extracellular matrix. In Vitro Cell Dev Biol Anim 29A, 339, 1993.

27. Hammar, E.B., Irminger, J.C., Rickenbach, K., et al. Activation of $\mathrm{NF}-\kappa \mathrm{B}$ by extracellular matrix is involved in spreading and glucose-stimulated insulin secretion of pancreatic beta cells. J Biol Chem 280, 30630, 2005.

28. Nagata, N., Gu, Y., Hori, H., et al. Evaluation of insulin secretion of isolated rat islets cultured in extracellular matrix. Cell Transplant 10, 447, 2001.

29. Edmondson, R., Broglie, J.J., Adcock, A.F., and Yang, L. Three-dimensional cell culture systems and their applications in drug discovery and cell-based biosensors. Assay Drug Dev Technol 12, 207, 2014.

30. Abbott, A. Cell culture: biology's new dimension. Nature 424, 870, 2003.

31. Voskuhl, J., Brinkmann, J., and Jonkheijm, P. Advances in contact printing technologies of carbohydrate, peptide and protein arrays. Curr Opin Chem Biol 18, 1, 2014.
32. Mendelsohn, A.D., Bernards, D.A., Lowe, R.D., and Desai, T.A. Patterning of mono-and multilayered pancreatic $\beta$-cell clusters. Langmuir 26, 9943, 2010.

33. MacGregor, R.R., Williams, S.J., Tong, P.Y., Kover, K., Moore, W.V., and Stehno-Bittel, L. Small rat islets are superior to large islets in in vitro function and in transplantation outcomes. Am J Physiol Endocrinol Metab 290, E771, 2006.

34. Lehmann, R., Zuellig, R.A., Kugelmeier, P., et al. Superiority of small islets in human islet transplantation. Diabetes 56, 594, 2007.

35. Nittala, A., Ghosh, S., and Wang, X. Investigating the role of islet cytoarchitecture in its oscillation using a new $\beta$-cell cluster model. PLoS One 2, e983, 2007.

36. Hammar, E., Parnaud, G., Bosco, D., et al. Extracellular matrix protects pancreatic $\beta$-cells against apoptosis. Diabetes 53, 2034, 2004.

37. Langhofer, M., Hopkinson, S.B., and Jones, J.C. The matrix secreted by $804 \mathrm{G}$ cells contains laminin-related components that participate in hemidesmosome assembly in vitro. J Cell Sci 105, 753, 1993.

38. Kuehn, C., Dubiel, E.A., Sabra, G., and Vermette, P. Culturing INS-1 cells on CDPGYIGSR-, RGD- and fibronectin surfaces improves insulin secretion and cell proliferation. Acta Biomater 8, 619, 2012.

39. Jiang, F.X., Georges-Labouesse, E., and Harrison, L.C. Regulation of laminin 1-induced pancreatic beta-cell differentiation by alpha6 integrin and alpha-dystroglycan. Mol Med 7, 107, 2001.

40. Nikolova, G., Jabs, N., Konstantinova, I., et al. The vascular basement membrane: a niche for insulin gene expression and $\beta$ cell proliferation. Dev Cell 10, 397, 2006.

41. Weber, L.M., and Anseth, K.S. Hydrogel encapsulation environments functionalized with extracellular matrix interactions increase islet insulin secretion. Matrix Biol 27, 667, 2008.

42. Wakayama, Y., Miura, K., Sabe, H., and Mochizuki, N. EphrinA1-EphA2 signal induces compaction and polarization of Madin-Darby canine kidney cells by inactivating Ezrin through negative regulation of RhoA. J Biol Chem 286, 44243, 2011.

Address correspondence to: Aart van Apeldoorn, PhD Complex Tissue Regeneration Department MERLN Institute for Technology Inspired Regenerative Medicine Maastricht University Maastricht 6229ER The Netherlands

E-mail: a.vanapeldoorn@maastrichtuniversity.nl

Received: June 11, 2018

Accepted: October 8, 2018

Online Publication Date: November 5, 2018 